УДК 347.132

DOI https://doi.org/10.32849/2663-5313/2019.8.04

\title{
Наталія Навальнева,
}

аспірантка кафедри щивільного права та прощесу

факультету № 6

Харківського національного університету внутрішніх справ

\section{КОНФІСКАЦІЙНІ САНКЦІЇ В ЦИВІЛЬНОМУ ПРАВІ ЗА ВЧИНЕННЯ НЕДІЙСНОГО ПРАВОЧИНУ}

Стаття присвячена аналізу конфіскаційних санкиій в чивільному праві, які можуть бути застосовані до сторін недійсного правочину, вчиненого з метою, що суперечить інтересам держави i суспільства. Автором обгрунтовано, що до конфіскаційних санкцій як визначених законом заходів иивільно-правового впливу, що полягають у припиненні права власності на майно, яке оплатно або безоплатно переходить у власність держави, належать одностороння реституиія та недопущення реституиї. Проведено історико-правовий аналіз розвитку иивільного законодавства про застосування односторонньої реституиї й аргументовано доцільність існування такої санкиї в ЦК України в сучасних умовах подолання корупиійних явищ, в Украӥні. Доведено, що одностороння реституиія та недопущення реституиї є особливими правовими наслідками недійсності правочину, вчиненого з метою, що завідомо суперечить інтересам держави $і$ суспільства, які застосовуються судом $i \epsilon$ заходами иивільно-правової відповідальності. Одностороння реституція не збігається з поняттям конфіскації майна у розумінні позбавлення права власності на майно за рішенням суду як санкцї за вчинення правопорушення. Уточнено, що односторонньою реституцією є повернення в первісний майновий стан однієі зі сторін недійсного правочину, яка не мала умислу вчинити правочин, що завідомо суперечить інтересам держави і суспільства, та стягнення за рішенням суду в дохід держави з іншої сторони, яка мала умисел вчинити правочин, визнаний судом недійсним як такий, що завідомо суперечить інтересам держави і суспільства, одержаного нею за правочином або належного їи на відикодування виконаного. Удосконалено поняття «недопущення реституиї» з уточненням, шо недопущенням реституиї є стягнення в дохід держави всього одержаного сторонами за правочином, а в разі виконання правочину не всіма сторонами - того, шо належало до одержання, за наявності умислу в обох сторін вчинити правочин, визнаний судом недійсним як вчинений з метою, що завідомо суперечить інтересам держави і суспільства.

Ключові слова: конфіскаційна санкція, недійсний правочин, публічний порядок, інтереси держави і суспільства, конфіскація, одностороння реституція, недопущення реституції.

Постановка проблеми. Прийняття Цивільного кодексу України від 16 січня 2003 р. (далі - ЦК України) [1] істотно змінило підходи в правовому регулюванні цивільно-правових наслідків недійсності правочину. Н. С. Кузнєцова зазначає, що принципова новела ЦК України 2003 року полягала в тому, що законодавець, визначаючи правові наслідки недійсності правочинів, взагалі відмовився від застосування конфіскаційних наслідків [2, с. 299]. Як стверджує 3. В. Ромовська, під час опрацювання проекту Цивільного кодексу України дебатувалося питання збереження конфіскаційної санкції (вилучення одержаного у дохід держави) у статті, що визнавала нікчемним правочин, який порушує публічний порядок, на випадок умислу однієї чи обох сторін [3, с. 388]. У частині 1 ст. 208 Господарського кодексу України від 16 січня 2003 р. [4] закріплено наслідки визнання господарського зобов'язання недійсним у вигляді стягнен- ня в дохід держави одержаного за недійсним господарським зобов'язанням, якщо його було вчинено з метою, яка завідомо суперечить інтересам держави і суспільства. Захист інтересів держави і суспільства під час вчинення правочину набув особливої актуальності у зв'язку з прийняттям Закону України від 02 грудня 2010 р. № 2756-VI «Про внесення змін до деяких законодавчих актів України у зв'язку з прийняттям Податкового кодексу України» [5], яким було внесено зміни до ст. 228 ЦК України і в частині 3 цієї статті було закріплено положення про односторонню реституцію.

Питання доцільності існування конфіскаційних санкцій у разі вчинення недійсного правочину, правова природа таких конфіскаційних заходів, їх види викликають і досі дискусію серед правників, зокрема цивілістів. У судовій практиці також виникають спірні питання щодо застосування конфіскаційних санкцій у разі вчинення правочину 
3 метою, що завідомо суперечить інтересам держави і суспільства, визначення юрисдикції суду, який має право розглядати справи про визнання правочину недійсним, якщо його було вчинено 3 недодержанням вимоги щодо відповідності правочину інтересам держави і суспільства.

Аналіз останніх досліджень і публікацій. Конфіскаційні санкції як різновид санкцій в цивільному праві вже досліджувалися в працях таких українських правників, як О. В. Дзера [6], О. О. Кот [7], Н. С. Кузнєцова [2], І. В. Спасибо-Фатєєва [8], та інших. Проте в цих дослідженнях здебільшого акцент ставився на правовій природі недійсних правочинів, їх загальних та особливих правових наслідках, а питання конфіскації найчастіше розглядалися в контексті цивільно-правової конфіскації власності як підстави припинення права власності.

Мета статті полягає у з'ясуванні сутності конфіскаційних санкцій у разі вчинення недійсного правочину, визначенні їх видів та обгрунтуванні доцільності (недоцільності) їх існування в цивільному праві.

Виклад основного матеріалу. Відповідно до ч. 1 ст. 216 ЦК України недійсний правочин не створює юридичних наслідків, крім тих, що пов'язані з його недійсністю. У разі недійсності правочину кожна зі сторін зобов'язана повернути другій стороні у натурі все, що вона одержала на виконання цього правочину, а в разі неможливості такого повернення, зокрема тоді, коли одержане полягає у користуванні майном, виконаній роботі, наданій послузі, - відшкодувати вартість того, що одержано, за цінами, які існують на момент відшкодування [1]. Н. С. Кузнєцова наголошує, що, аналізуючи наведені новели ЦК України 2003 р., можна констатувати, що вони цілком логічно вписуються в концепцію приватноправового методу регулювання майнових і особистих немайнових відносин, заснованих на юридичній рівності сторін і автономії їхньої волі. Як уже зазначалося раніше, порушення умов дійсності правочину само по собі не перетворює цю дію на правопорушення, воно позбавляє цю дію («волевиявлення», за М. М. Агарковим) статусу юридичного факту. Саме тому повернення сторін у первісний майновий стан (двостороння реституція) в цьому разі може розглядатися як найбільш адекватний правовий наслідок [2, с. 299-300]

Проте частиною 3 ст. 228 ЦК України передбачено, що в разі недодержання вимоги щодо відповідності правочину інтересам держави і суспільства, його моральним засадам такий правочин може бути визнаний недійсним. Якщо визнаний судом недійсний правочин було вчинено з метою, що завідомо суперечить інтересам держави і суспільства то за наявності умислу в обох сторін - в разі виконання правочину обома сторонами - в дохід держави за рішенням суду стягується все одержане ними за угодою, а в разі виконання правочину однією стороною 3 іншої сторони за рішенням суду стягується в дохід держави все одержане нею і все належне - 3 неї першій стороні на відшкодування одержаного. За наявності умислу лише в однієї зі сторін все одержане нею за правочином повинно бути повернуто іншій стороні, а одержане останньою або належне їй на відшкодування виконаного за рішенням суду стягується в дохід держави [1].

Такі зміни в цивільному законодавстві України викликали критику серед правників. Так, Н. С. Кузнєцова наголошує, що не менш проблематичним стало доповнення в 2010 р. ст. 228 ЦК «Правові наслідки вчинення правочину, який порушує публічний порядок». Крім зміни самої назви статті, яка зараз іменується «Правові наслідки вчинення правочину, який порушує публічний порядок, вчинений з метою, що суперечить інтересам держави та суспільства», вона була доповнена ч. 3, що фактично «реанімувала» ст. 49 ЦК УРСР, від якої розробники ЦК принципово відмовилися, замінивши механізм цивільно-правової конфіскації застосуванням реституції з можливим стягненням збитків та компенсацією моральної шкоди (ст. 216 ЦК України) [9, с. 43].

О. Дзера зазначає, що в ч. 3 ст. 228 ЦК передбачені різнопорядкові правові наслідки недійсності правочину. 3 її змісту випливає, що у разі недотримання вимог щодо відповідності правочину інтересам держави і суспільства він може бути визнаний недійсним. Отже, ця норма не зобов'язує суд визнавати такий правочин недійсним, що дає підстави відносити його до категорії оспорюваних правочинів. Якщо це так, то повинні застосовуватися загальні правові наслідки у вигляді двосторонньої чи односторонньої реституції, передбаченої ст. 216 ЦК України. У тому ж разі, якщо вищезазначений правочин вчинений також з метою, що суперечить інтересам держави і суспільства, то за наявності умислу в обох сторін або в однієї сторони повинні застосовуватися відповідно двостороння або одностороння конфіскація одержаного чи того, що належить, за таким правочином. У цьому випадку застосування конфіскаційної санкції передбачено імперативною нормою [10, с. 315]. Наведені положення свідчать, що в законодавстві відсутнє легальне визначення односторонньої реституції, 
в юридичній літературі також немає однакового тлумачення поняття «одностороння реституція».

Одностороння реституція означає приведення в первинний стан лише невинуватої сторони шляхом повернення цій стороні виконаного нею за правочином і стягнення в дохід держави одержаного винуватою стороною або того, що належить цій стороні як відшкодування виконаного нею за правочином [11, с. 177]. Саме таке розуміння односторонньої реституції є традиційним у цивілістичній літературі. Хоча, наприклад, I. СпасибоФатєєва зазначає, що у разі винесення судом рішення про повернення майна лише одній стороні правочину на іï вимогу ми матимемо своєрідну односторонню реституцію. Своєрідність іï полягає в тому, що вона не відбиває розуміння, яке закладалося в це поняття за радянських часів: тоді сформувалося уявлення про односторонню реституцію як певну санкцію, коли одній стороні правочину повертається майно, а з другої стягується одержане нею за недійсним правочином на користь держави. При цьому, на думку I. Спасибо-Фатєєвої, навіть якщо говорити про конфіскацію, що настає в певних випадках правопорушень, яких припустились сторони правочину, то вона застосовується як окремий наслідок недійсності правочинів, а не як одностороння реституція [8, с. 165].

3'ясуємо більш ретельно сутність односторонньої реституції в цивільному праві та їі співвідношення з конфіскаційними санкціями.

Одностороння реституція історично походить 3 кондикції на користь держави, як це мало місце в ЦК УСРР від 16 грудня 1922 р. [12, с. 325]. Зокрема, згідно зі ст. 147 ЦК УСРР від 16 грудня 1922 р. у разі недійсності договору, як протизаконного або спрямованого на очевидної шкоду для держави (ст. 30), жодна сторона не має права вимагати від іншої повернення виконаного за договором. Безпідставне збагачення стягується на прибуток держави (ст. 402) [13]. В. О. Кучер зазначає, що до прийняття цього Кодексу стягнення в дохід держави як наслідку учинення протиправного правочину наука та судова практика не знали, тому такі наслідки обмежувалися лише відновленням майнового становища сторін, яке існувало до вчинення правочину, а також відшкодуванням винною стороною заподіяної шкоди іншим особам [14, с. 155].

Згідно зі ст. 49 Цивільного кодексу УРСР від 18 липня 1963 р., якщо угода укладена з метою, завідомо суперечною інтересам соціалістичної держави і суспільства, то за наявності умислу в обох сторін - в разі виконання угоди обома сторонами - в доход держави стягується все одержане ними за угодою, а в разі виконання угоди однією стороною з другої сторони стягується в доход держави все одержане нею і все належне з неї першій стороні на відшкодування одержаного. За наявності ж умислу лише у однієї зі сторін все одержане нею за угодою повинно бути повернуто другій стороні, а одержане останньою або належне їй на відшкодування виконаного стягується в доход держави [15]. 3 огляду на характер цих наслідків, вони отримали назву цивільно-правової конфіскації [2, с. 298]. Відповідно до ЦК УРСР в літературі почав вживатися термін «одностороння реституція», коли поверталося те, що було передано за угодою лише однією стороною. А те, що було передано другою, винною, стороною, стягувалося в дохід держави [16, с. 150].

O. С. Йоффе зазначає, що одностороння реституція полягає в тому, що один з учасників правочину одержує виконане назад i, отже, відновлюється в попередньому стані, а виконання, одержане від другого контрагента, останньому не повертається і стягується в дохід держави [17, с. 300].

Бачиться, що доцільно дотримуватися усталених підходів цивілістів до поняття односторонньої реституції, не замінюючи це поняття на односторонню конфіскацію, зважаючи, що поняття конфіскації надано в ч. 1 ст. 354 ЦК України. Одностороння реституція $є$ санкцію в цивільному праві за вчинення недійсного правочину як протиправної дії за умови наявності умислу лише в однієї зі сторін вчинити правочин з метою, що завідомо суперечить інтересам держави і суспільства. Одностороння реституція означає повернення в первісний майновий стан однієї зі сторін недійсного правочину, яка не мала умислу вчинити правочин, що завідомо суперечить інтересам держави і суспільства, та стягнення за рішенням суду в дохід держави з іншої сторони, яка мала умисел вчинити правочин, визнаний судом недійсним як такий, що завідомо суперечить інтересам держави і суспільства, одержаного нею за правочином або належного їй на відшкодування виконаного.

Одностороння реституція в такому розумінні $є$ заходом цивільно-правової відповідальності й належить до конфіскаційних санкцій, виходячи з того, що конфіскаційними санкціями в цивільному праві є визначені законом заходи цивільно-правового впливу, що полягають у припиненні права власності на майно, яке оплатно або безоплатно переходить у власність держави.

На недоцільність існування односторонньої реституції вказували, зокрема, О. А. Пушкін та В. М. Самойленко, на думку яких, якщо 
у діях сторін будуть наявні ознаки злочину чи адміністративного правопорушення, до них повинні застосовуватися відповідні санкції, але вже ті, що містяться в нормах публічного права [18, с. 231]. Аналогічної позиції дотримується й О. В. Семушина [19].

Враховуючи необхідність захисту публічних інтересів держави і суспільства, існування односторонньої реституції як особливого правового наслідку недійсності правочину в умовах боротьби з корупційними явищами в державі є доцільним та обгрунтованим задля забезпечення виконання державою своїх завдань перед суспільством та людиною. Наявність публічно-правових норм в ЦК України жодним чином істотно не впливає на приватноправовий механізм регулювання цивільних відносин, заснованих на юридичній рівності, вільному волевиявленні, майновій самостійності іх учасників, а сприяє більш ефективному захисту цивільних прав та інтересів учасників цивільних правовідносин та захисту інтересів держави і суспільства цивільно-правовими заходами.

У частині 3 ст. 228 ЦК України йдеться про те, що за наявності умислу вчинити правочин з метою, що завідомо суперечить інтересам держави і суспільства, в обох сторін - в разі виконання правочину обома сторонами - в дохід держави за рішенням суду стягується все одержане ними за угодою, а в разі виконання правочину однією стороною з іншої сторони за рішенням суду стягується в дохід держави все одержане нею і все належне - 3 неї першій стороні на відшкодування одержаного. О. В. Гутников зазначає, що в разі, якщо вина в скоєнні протизаконного недійсного правочину є в обох сторін цього правочину, то має місце недопущення реституції. При цьому конфіскаційні заходи у вигляді стягнення одержаного в дохід держави рівною мірою застосовуються до обох сторін недійсного правочину [20, с. 249]. Недопущення реституції в юридичній літературі визначається як стягнення в дохід держави всього одержаного сторонами за правочином, а в разі виконання правочину не всіма сторонами - того, що належало до одержання [11, с. 177].

Отже, недопущення реституції як особливий правовий наслідок недійсності правочину, вчиненого з метою, що завідомо суперечить інтересам держави і суспільства, застосовується судом, є конфіскаційною санкцією та заходом цивільно-правової відповідальності і являє собою стягнення в дохід держави всього одержаного сторонами за правочином, а в разі виконання правочину не всіма сторонами - того, що належало до одержання, за наявності умислу в обох сторін вчинити правочин, визнаний судом недійсним як вчинений з метою, що завідомо суперечить інтересам держави і суспільства.

\section{Висновки}

Підсумовуючи розгляд питання про конфіскаційні санкції в цивільному праві у разі вчинення недійсного правочину, необхідно зазначити, що до конфіскаційних санкцій як визначених законом заходів цивільно-правового впливу, що полягають у припиненні права власності на майно, яке оплатно або безоплатно переходить у власність держави, належать одностороння реституція та недопущення реституції. Одностороння реституція та недопущення реституції є особливими правовими наслідками недійсності правочину, вчиненого з метою, що завідомо суперечить інтересам держави і суспільства, які застосовуються судом і є заходами цивільно-правової відповідальності. Одностороння реституція не збігається з поняттям конфіскації майна у розумінні позбавлення права власності на майно за рішенням суду як санкції за вчинення правопорушення. Односторонньою реституцією є повернення в первісний майновий стан однієї зі сторін недійсного правочину, яка не мала умислу вчинити правочин, що завідомо суперечить інтересам держави і суспільства, та стягнення за рішенням суду в дохід держави з іншої сторони, яка мала умисел вчинити правочин, визнаний судом недійсним як такого, що завідомо суперечить інтересам держави і суспільства, одержаного нею за правочином або належного їй на відшкодування виконаного. Недопущення реституції являє собою стягнення в дохід держави всього одержаного сторонами за правочином, а в разі виконання правочину не всіма сторонами - того, що належало до одержання, за наявності умислу в обох сторін вчинити правочин, визнаний судом недійсним як вчиненого з метою, що завідомо суперечить інтересам держави і суспільства.

\section{Список використаних джерел:}

1. Цивільний кодекс України від 16 січня 2003 р. № 435-IV. Відомості Верховної Ради України. 2003. № 40-44. Ст. 356.

2. Кузнецова Н. Недействительность сделок (к вопросу об антисоциальных сделках и последствиях их совершения). Ежегодник украинского права. 2012. № 4. С. 293-306.

3. Ромовська 3. Українське цивільне право: Загальна частина. Академічний курс : підручник. Київ : Атіка, 2005. 560 с.

4. Господарський кодекс України від 16 січня 2003 р. № 436-IV. Відомості Верховної Ради України. 2003. № 18, № 19-20, № 21-22. Ст. 144. 
5. Про внесення змін до деяких законодавчих актів України у зв'язку з прийняттям Податкового кодексу України : Закон України від 02 грудня 2010 р. № 2756- VI. Відомості Верховної Ради Украӥни. 2011. № 23. Ст. 160.

6. Дзера О. Цивільно-правова конфіскація в контексті змін ст. 228 ЦК України. Право України. 2011. № 5. C.69-76.

7. Кот О. Природа недійсних правочинів. Вісник Національної академії правових наук Українu. 2009. № 4. C. 108-118.

8. Спасибо-Фатєєва I. Недійсні правочини та проблеми застосування реституції. Щорічник украӥнського права. 2009. № 1. С. 150-167.

9. Кузнєцова Н. С. Перспективи розвитку приватного права в контексті європейської інтеграції України. Проблеми цивільного права та прочесу : тези доп. учасників наук.-практ. конф., присвяч. світлій пам'яті О. А. Пушкіна (Харків, 25 травня 2018 р.). Харків : ХНУВС, 2018. С. 40-46

10. Дзера А. Некоторые вопросы гражданско-правовой конфискации по законодательству Украины. Ежегодник украинского права. 2012. № 4. С. $307-318$.

11. Гражданское право. Часть первая : учебник / под ред. А. Г. Калпина, А. И. Масляева. Москва : Юристь, 1997. 472 с.

12. Навальнєва Н. М. Одностороння реституція як санкція у цивільному праві. Проблеми иивільного права та процесу : тези доп. учасників наук.-практ. конф., присвяч. світлій пам'яті
О. А. Пушкіна (Харків, 19-20 травня 2017 р.). Харків : ХНУВС, 2017. С. 324-326.

13. Цивільний кодекс УСРР від 16 грудня 1922 p. URL : https://deminov.dp.ua/grazhdanskoepravo-i-process/ck-codecs-ussr-1922 (дата звернення: 25.07.2019).

14. Кучер В. О. Нікчемні правочини дис. ... канд. юрид. наук : 12.00.03. Київ, 2004. 208 с.

15. Цивільний кодекс УРСР від 18 липня 1963 р. № 1540-VI. URL : https://zakon.rada. gov.ua/laws/show/1540-06 (дата звернення: 20.06.2019)

16. Ромовська 3. В. Недійсність правочинів. Практика застосування окремих норм Цивільного кодексу Украӥни : практ. посіб. / кол. авт. Київ : Видавничий Дім «Ін Юре», 2008. С. 102-151.

17. Иоффе О. С. Советское гражданское право. Москва : Юрид. лит., 1967. 494 с

18. Гражданское право Украины : учебник для вузов системы МВД Украины : в 2-х частях. Часть 1 / А. А. Пушкин, В. М. Самойленко, Р.Б. Шишка и др.; под. ред. проф. А. А. Пушкина, доц. В. М. Самойленко. Харьков : Основа, 1996. 440 с.

19. Семушина О. В. Недійсні правочини та правові наслідки їх недійсності : автореф. дис. ... канд. юрид. наук : 12.00.03. Київ, 2010. 16 с. URL : http://irbis-nbuv.gov.ua/cgi-bin/irbis64r_81/ cgiirbis_64.exе (дата звернення: 19.07.2019).

20. Гутников О. В. Недействительные сделки в гражданском праве. Теория и практика оспаривания. Москва : Бератор-Пресс, 2003. 576 с.

The article is focused on the analysis of forfeiture sanctions in civil law, which can be applied to the parties to an invalid transaction committed for the purpose of contradicting the interests of the state and society. The author has substantiated that unilateral restitution and denial of restriction belong to confiscation sanctions established by the law measures of civil and legal influence, which imply the termination of the ownership for property that becomes state property on a paid basis or free of charge. Historical and legal analysis of the development of civil legislation on the application of unilateral restitution has been carried out and the expediency of the existence of such a sanction in the Civil Code of Ukraine in the current conditions of overcoming corruption phenomena in Ukraine has been substantiated. It has been proved that unilateral restitution and denial of restitution are special legal consequences of the invalidity of a transaction made with the purpose to knowingly contradicting the interests of the state and society applied by the court and that are measures of civil liability. Unilateral restitution does not coincide with the concept of confiscation of property in the sense of deprivation of ownership for property by the court decision as a sanction for committing the offense. It has been clarified that unilateral restitution is the return to the original property state of one of the parties to the invalid transaction that did not have an intent to make a transaction, which is deliberately contradicts to the interests of the state and society, as well as recovery by the court decision to the income of the state from the other party that intentionally made a transaction declared invalid by the court as such, which is knowingly contradicts to the interests of the state and society obtained by the transaction or owned for the compensation of the accomplished. The concept of "denial of restitution" has been improved with the clarification that denial of restitution is the recovery of all received by the parties within the transaction to the income of the state, and in case of execution of the transaction not by all parties - everything belonging before reception, if there is the intent of both parties to make the transaction recognized by the court as invalid, committed for the purpose of knowingly contradicting the interests of the state and society.

Key words: confiscation sanction, invalid transaction, public order, interests of the state and society, confiscation, unilateral restitution, denial of restitution. 